Proc. Estonian Acad. Sci. Geol., 2005, 54, 2, 119-136

\title{
Development and protection of the coasts in the Tallinn area
}

\author{
Heino Levald ${ }^{\mathrm{a}}$ and Ain Valdmann ${ }^{\mathrm{b}}$ \\ a Estonian Maritime Academy, Mustakivi 25, 13912 Tallinn, Estonia; heino.levald@mail.ee \\ b Tallinn Municipal Engineering Services Department, Mündi 2, 10146 Tallinn, Estonia; \\ ain.valdmann@tallinnlv.ee
}

Received 16 February 2005, in revised form 14 April 2005

\begin{abstract}
The paper deals with the protection of the coastal areas of Tallinn and their primary development into harbours. The coast and coastal buildings are endangered by strong storm waves, especially in case of a high sea accompanying the storm. Due to the influence of waves, the coastal terrace recedes towards the land; in the bays the sands are whether deposited or swept away. Storms have caused major destruction to the coasts of Aegna Island and the Kakumäe Peninsula. The coastal area owners, the local authorities, and the organs of the state should take measures to protect the coasts through mutual cooperation and improvement of the valid legislation. The coasts and harbours within the boundaries of Tallinn are predominantly state-owned. In planning the development of the harbours it is necessary to reckon with the increase in passenger transport and sea tourism, environmental protection, safety and economic interests of the city, which have so far been somewhat neglected. Tallinn Municipality has begun to rearrange the administration of the coasts and harbours located within the city borders. Muuga Harbour plays a special role in further protection of coasts and development of harbours and could take over a major part of cargo transport within the boundaries of Tallinn. To ensure the safety of the harbour, a breakwater has to be constructed, however, it is a complicated and expensive task due to difficult geological conditions. The research conducted shows that the breakwater would increase considerably the safety of the harbour and is economically cost-effective.
\end{abstract}

Key words: Tallinn, coast, coastal reinforcement, harbour, breakwaters, environmental impact, cost-benefit analysis.

\section{INTRODUCTION}

The protection and usage of coastal areas in the vicinity of Tallinn have been a long-debated issue due to the geological peculiarities of the area and alteration of the coastline under the impact of nature and port construction. Problems have also 
arisen with obtaining the materials for the reinforcement of the coast and port buildings and arrangement of cooperation between the owners of coastal areas and local authorities administering the state and coastal areas, aimed at the protection and development of the coasts. These problems have been solved in various ways in different periods of the history of Tallinn. In the past decades the proprietary relations and the administration of coastal areas have undergone a drastic change. The present paper deals with the problems related to the protection and development of coasts and with the possible solutions that could be reached by the owners of coastal lands and buildings in cooperation with the state and local authorities under the present legislation.

The present treatise considers as the Tallinn area the part of the Gulf of Finland stretching from Kakumäe Bay to Muuga Bay, including Aegna, Naissaar, and Prangli islands (Fig. 1). The islands, peninsulas, and shallows make up an area relatively well protected from the waves, with coasts suitable for harbours, which has favoured the development of Tallinn as a city of harbours, where people and companies form a socio-economic whole. The problems of the protection and development of the coasts of that area and their solution are closely connected with each other and with Tallinn city as the centrum.

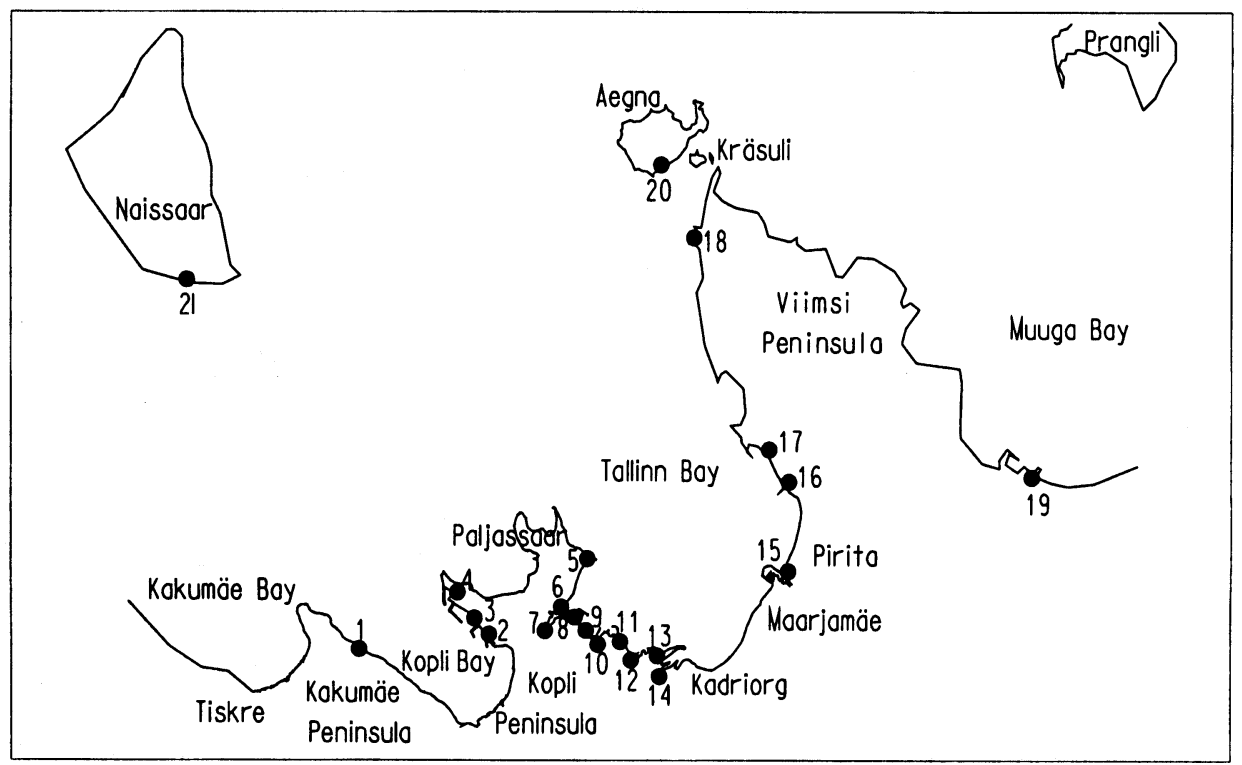

Fig. 1. The coast and harbours of the Tallinn area. 1, Kakumäe Harbour; 2, Meeruse Harbour; 3, Bekkeri Harbour; 4, Vene-Balti Harbour; 5, Katariina Quay; 6, Paljassaare Harbour; 7, Lahesuu Harbour; 8, Hundipea Harbour; 9, Miinisadam Harbour; 10, Peetrisadam Harbour; 11, Lennusadam Harbour; 12, Kalasadam Harbour; 13, Patareisadam Harbour (called also Linnahalli Harbour); 14, Vanasadam Harbour; 15, Pirita Harbour; 16, Merivälja Quay; 17, Miiduranna Harbour; 18, Rohuneeme Harbour; 19, Muuga Harbour; 20, Aegna Harbour; 21, Naissaare Harbour. 


\section{GEOLOGICAL SETTING OF THE TALLINN AREA}

The geology of the Tallinn area has been thoroughly studied (e.g. Tammekann 1934; Künnapuu \& Raukas 1976; Valt et al. 1979; Raukas \& Hyvärinen 1992). The geological structure of the area is typical of the whole southern coast of the Gulf of Finland, represented by the so-called foreklint lowland with its peculiar indented shoreline and numerous islands. There are several shallows and rocky reefs, sometimes emerging above the water level in the coastal sea and endangering navigation.

The Proterozoic crystalline basement in the Tallinn area is covered with the Upper Proterozoic and Lower Palaeozoic rocks, up to the Middle Ordovician (some 460 million years ago). The upper boundary of the basement is at a depth of 130-150 m b.s.l. (Nõlvak 1997). The sedimentary cover has a gentle southward inclination, on average 3-4 m per $\mathrm{km}$. On the basis of the lithology of sedimentary rocks, the Lower Palaeozoic in Tallinn can be divided into two parts: (1) the Vendian, Cambrian, and the lowermost Ordovician (Tremadockian), composed mostly of terrigenous rocks, and (2) the Ordovician from the Arenig to the Lower Caradoc, formed prevailingly of carbonate and fine-terrigenous rocks (Nõlvak 1997). Cambrian sand- and siltstones crop out at Rocca-al-Mare and in the valley of the Pirita River. The bedrock topography within the town and its surroundings is characterized by several relative small positive (Toompea, Sõjamägi, etc.) and negative features (Tavast \& Raukas 1982). The most notable positive relief form is the North Estonian Klint, which consists of rocks of variable hardness. The section at Suhkrumägi displays pure hard limestones and dolostones in the topmost $6.5 \mathrm{~m}$, which are underlain by soft Cambrian and Ordovician terrigenous rocks. The klint is highest at Maarjamägi, where it rises to $47 \mathrm{~m}$ a.s.l. In some places at the foot of the klint, there are terraces of different stages of the postglacial Baltic Sea.

The klint divides Tallinn and its surroundings into two geomorphologically markedly distinct areas: the limestone plateau and the foreklint lowland (Tammekann 1934). The latter is significant from the marine aspect and all the harbours of Tallinn are located here. From the engineering-geological perspective, regular alteration of highlands of different heights (Kakumäe, Kopli, Viimsi, etc.) and plains (Harku, Lilleküla, Kadrioru, Pirita, etc.), and the existence of valleys cut deep into the foreklint plains (Künnapuu \& Raukas 1976) are of importance. One valley, with an approximate depth of $100 \mathrm{~m}$, proceeds from the western coast of Lake Ülemiste to Kopli Bay; another, a couple of dozen metres less deep, from an area between Toompea and Lasnamäe to Tallinn Bay; a third one, $145 \mathrm{~m}$ deep, from below Lake Harku to Kakumäe Bay. These are ancient river valleys, formed already in pre-Quaternary time and subsequently reshaped by glaciers and their meltwaters (Tavast \& Raukas 1982).

Pleistocene glacial deposits in the foreklint lowland are covered by the sediments of the local ice-lakes and the Baltic Sea. The thickness of soft varved clays amounts to $10 \mathrm{~m}$. The most prominent coastal forms, about $35 \mathrm{~m}$ high, are referred to the 
initial stage of the Ancylus Lake, when the shoreline remained stable for a long time, favouring the formation of extensive scarps and accumulation of sediments in Tallinn. The Litorina Sea deposits and coastal forms are observed at a height of $12-23 \mathrm{~m}$ a.s.1. By the beginning of the Limnea Sea 4000 years ago, the last stage in the Baltic Sea development, the water had dropped to the present-day level.

The uplift of the Earth's crust takes place at present as well, however it is not as intensive as before, only 1-2 mm/yr. In the 13th-14th centuries the sea reached almost as far as the present Viru hotel and the area of Narva Street was presumably under the water. The port of Tallinn was situated evidently near the Big Coast Gate (Künnapuu \& Raukas 1976).

The sea controls the development of the Tallinn relief also nowadays. At the tops of peninsulas it abrades the coast, and evidence has been derived of contemporary erosional scarps in Kakumäe, Kopli, and Merivälja. Sandy deposits accumulate at the tops of the bays as, for example, in Kopli Bay and Pirita.

\section{DANGERS TO THE COASTS OF THE TALLINN AREA}

Tallinn is a good natural area for harbours. The harbours have existed here since the foundation of the town on a trade route in the 11th century. The Hansa, a powerful economic unit of the Baltic towns, had great influence on the construction and expansion of the port in Tallinn. Riga and Tallinn were among the first to join the Hanseatic League (on 15 March 1285).

However, the coastal area and harbours of Tallinn are open to northwestern and northern storms. The coasts and the buildings on the coast and in coastal waters (harbours, quays, breakwaters, etc.) are endangered mainly by the high storm waves formed by strong winds, which are able to shift the sediments in the coastal area, and also by the currents that can obtain a high speed with gales, and a sudden rise in the water level. A permanent ice cover inhibits the formation of storm waves and therefore spares the shore, but pack ice that can be formed out of a permanent ice cover during a storm, is particularly dangerous to the coasts and buildings. The impact of the sea on the coasts has been thoroughly investigated by Orviku $(1987,2000)$. Several researchers have assessed environmental impacts, including the influence of waves (e.g. Järvik 2002; Levald 2004).

The waves generated by fast boats are also considered as dangerous to the shores. The research has shown that their impact differs from the one of the natural waves, being negative on the marine environment (Soomere et al. 2003) and the use of the shores, however, their considerable negative impact on the shore and coastal buildings has not been proven yet (Orviku 2000).

Till shores are relatively resistant to storm waves. Storm waves abrade from till the finer sediments: mud, clay, sand, and gravel. Only the part of the abraded till, which the waves would be unable to move, will remain on the shore. The remaining harder and heavier rocky material forms a bench protecting the coast from further abrasion. Sometimes there may form also walls of gravel, when the 
initial rock includes enough material with the proper grain size. The motion of the waves in such boulder-rich coasts is restricted and in some places vegetation will develop in between the boulders.

Yet, morainic terraces typically recede towards the land due to the impact of the sea. The processes that have taken place on the coastal terraces are displayed by their recent nature, fallen trees, big boulders, etc. The recession of the coastal terrace decreases the land area at the site and can impair the buildings, roads, and other facilities located nearby and make them unfit for use.

The most serious damage happens at such shores in the autumn-winter season with severe storms, accompanied by a high seawater level. During warm winters the formation of storm waves and their impact has been favoured by the absence of sea ice, in cold winters, by the movement of pack ice. Extremely unfavourable conditions cause essential spasmodic changes of the coasts: the coastal terraces are heavily damaged, in places high quantities of sand are swept away from the sandy coasts, in other places massive accumulation of coastal sediments takes place. A severe storm occurred in January 2005, which caused extensive destruction to the coasts of Aegna Island and the Kakumäe Peninsula and damage to several buildings. According to the observations of the inhabitant of Aegna and the nature protection activist, Hugo Udusaar, the shoreline on the western coast of the island has shifted in places for 10-15 m towards the inland. About 100 trees have fallen to the sea, and a similar number of trees have been rooted up. Also, part of the road has been swept away. One house remained only $7 \mathrm{~m}$ from the sea, with the overhead line and the water pipeline on the water boundary. The basic construction of the wharf was damaged, the cover, the border, and the seamarks were destroyed (Figs. 2, 3). In order to prevent any such damage, the coasts need to be reinforced in a more effective manner. The research of the damage caused yields good base material for this task.

The displacement of sand or its accumulation is a typical damage to the sandy coasts of the bays. Due to the displacement of the sand the buildings and facilities located too close to the shoreline can be damaged in case of a high sea and storm. The accumulation of the sand can have both positive and negative effect. Special reinforcements of the coasts enable either avoiding the displacement of sand or increasing its accumulation, according to the need.

The incompetent alteration of the shoreline by humans usually weakens the natural ability of the coast to resist the storm waves, quickens the abrasion, and extends the scope of the coastal damage in places with a natural prevalent recession of the shoreline towards the land. This can result in the continuation of the coastal damage and the extension of the area suffering from the storm damage to both sides along the shoreline, jeopardizing also the adjacent coasts.

In order to prevent the damage to the coasts, projects have to be made for each coastal protection measure and other objects planned to the coast, their thorough expertise should be conducted and environmental impacts assessed, considering the cumulative effect of the natural conditions and all the facilities and other objects nearby. The largest coastal defence building is the Pirita road, stretching from 
Kadriorg to Pirita. Some coastal protection buildings occur also in other regions. Several of these were heavily damaged in the storm of January 2005, except for those with expert planning and of high-quality construction.

The coasts and coastal facilities and buildings get damaged mainly if the valid requirements and practical experience have not been taken into account at their planning stage, or if the construction is of low quality and as inexpensive as possible. Sometimes the damage may also be caused by the shortcomings of the valid legislative acts. Thus the minimal allowed distance from the shoreline has been validated for constructing the buildings, but the requirement for minimal height from the mean water level (the Kroonlinn zero) has not yet been enforced. The results of the January 2005 storm in Pärnumaa and Läänemaa demonstrate the need for local height restrictions. In planning the harbours, bridges, and other major seaside objects it is necessary to conduct, besides meeting all the demands of valid legislative acts, also the required scientific research to forecast the possible dangers.

\section{THE CONDITION OF THE TALLINN AREA COASTS AND THEIR PROTECTION}

The coasts of the Tallinn area are under the administration of several local authorities. Besides the city of Tallinn, they include Harku Rural Municipality in the west, and Viimsi and Jõelähtme rural municipalities in the east. Aegna Island lies within the administrative boundaries of Tallinn, while Naissaar, Prangli, and Kräsuli islands are located on the territory of Viimsi Rural Municipality.

The coasts and coastal areas belong to several owners, including the state and the local authorities, and their number is gradually increasing. Some coastal areas are still not reformed. The coastal lands and harbours in the administrative area of the city of Tallinn are mainly state-owned. Kalasadam Harbour, Pirita Harbour, Merivälja Quay, and Rohuneeme Harbour are a private property. Tallinn has only Patareisadam Harbour in its ownership. In all the harbours, functioning as trading companies, there are also active operator firms and leaseholders, many of them having their own property in the harbours.

The wide circle of the coast and harbour owners and administrators and the combination of their interests, rights, obligations, and potential complicate settling the coastal protection and development issues. The primary causes underlying the drawbacks in this matter are the careless and negligent attitude of several owners, their ignorance and economic incapacity and the resultant lack of the required facilities or the unpurposeful thrift of resources and technical failures in building them. Besides the care of each party involved, the effective continuous coastal protection requires also a good mutual cooperation of the parties. Otherwise the coastal protection or the alteration of shoreline that has been carried out with good intents will only harm the neighbouring areas and worsen the general condition. The local authorities and the Harju County Government uniting them play a leading 


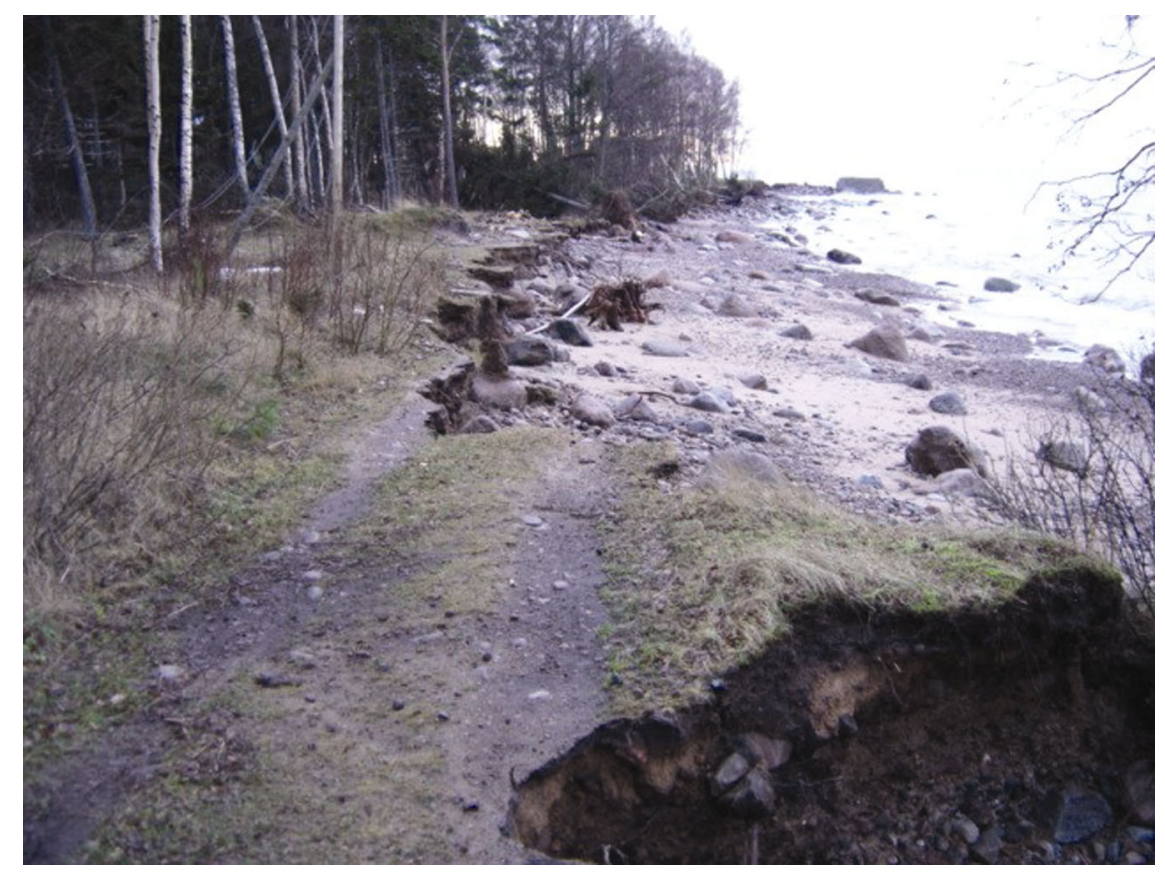

Fig. 2. The damage to the Aegna Island coast after the storm in January 2005 (Photo by H. Udusaar).

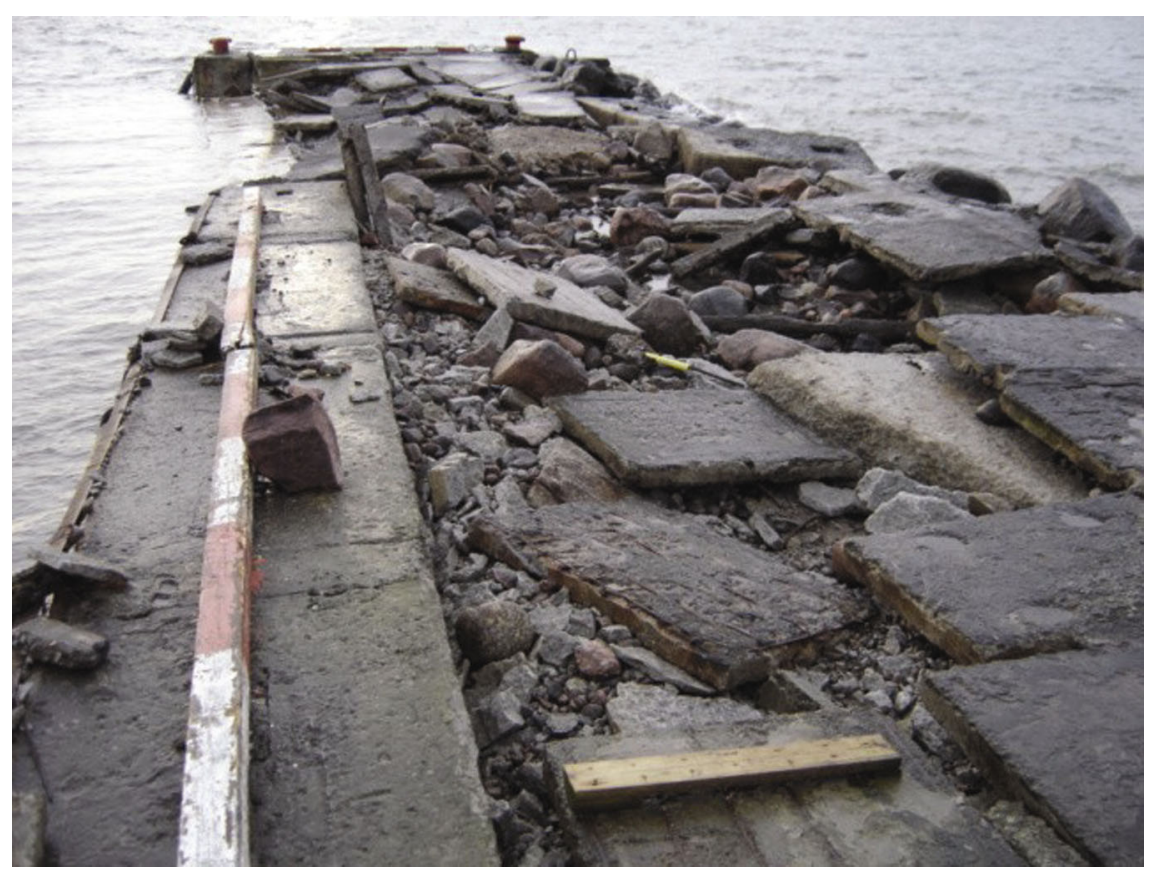

Fig. 3. The damage caused to Aegna Harbour by the storm in January 2005 (Photo by H. Udusaar). 


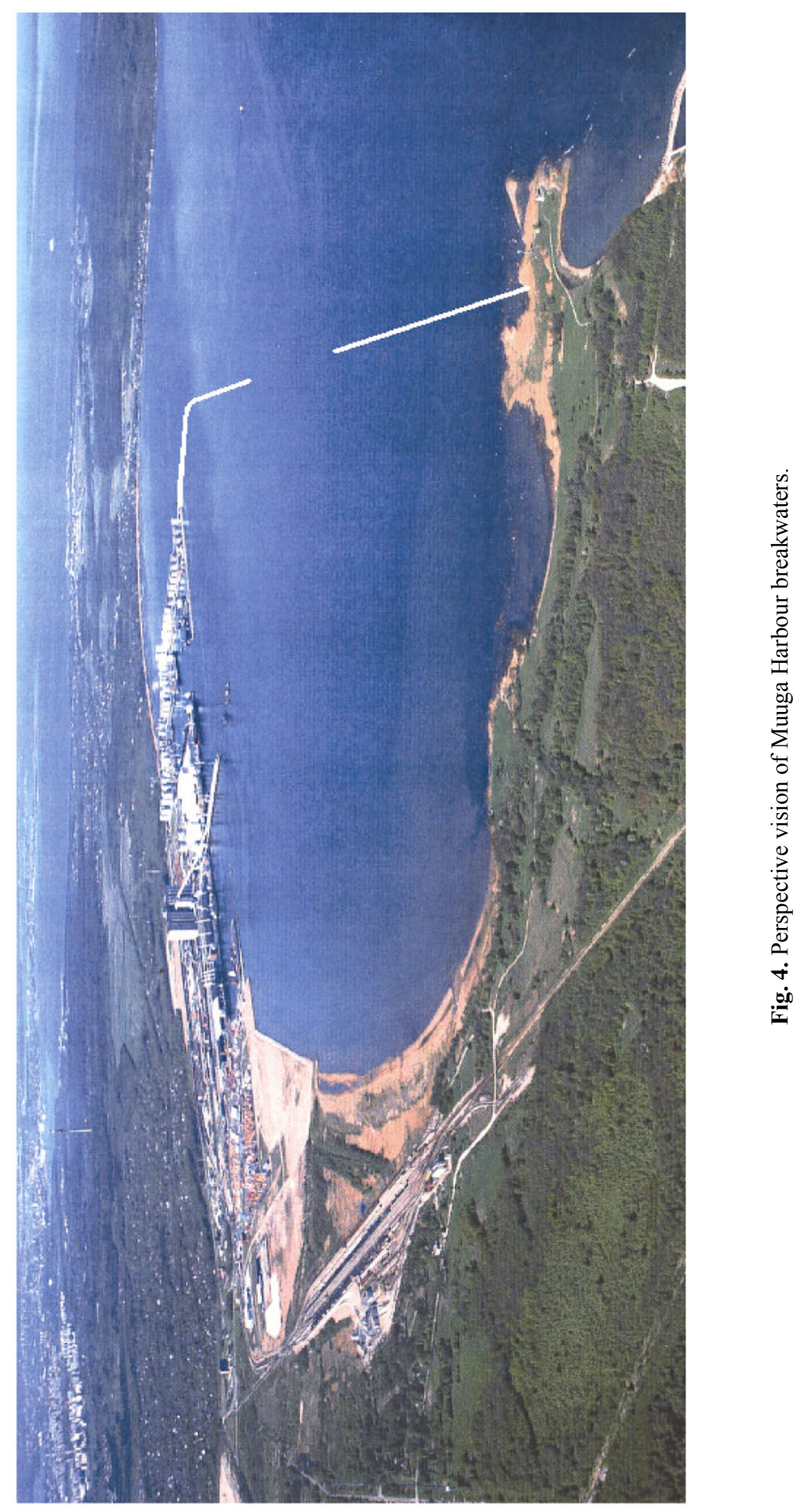


role in the regulation of their cooperation. Tallinn Municipality and the Viimsi Rural Municipality Government play the main role in the regulation and realization of coastal protection.

As well as the entire marine legislation of Estonia, the legislation covering the protection of coasts and their development is still in its formation stage and does not provide solutions to all problems. The local authorities, including Tallinn Municipality, have to consider this in their attempts to regulate the protection and development of coasts.

\section{THE CONDITION OF TALLINN HARBOURS AND THEIR DEVELOPMENT}

As a rule, the harbours of the Baltic Sea are whether the property of the city or a local authority, administering the territory of their location. This aspect guarantees the recognition of local interests in the planning of harbours, which may recede to the background in the course of the development of harbours in the interests of the state or private owners. Besides, a well-functioning harbour is an efficient generator of income and a development mechanism to the local authority. Also in Tallinn the harbours belonged to the city until the late Middle Ages, but as Russia changed these to military ports, they were transferred into the state ownership and continued to be in that status also after Estonia gained its independence. The city got only re-established Patareisadam Harbour with Linnahalli Harbour and later on also Kalasadam Harbour into its possession, with the immediate privatization of the latter, after its conveying to the city. The remaining harbours of Tallinn and the land under these are owned by the state. Such a situation has made the use, maintenance, and development of Tallinn harbours very problematic. The state has not made any plans for the development of the harbours in its ownership and has also avoided cooperation in this field with Tallinn Municipality, who has repeatedly turned with the respective suggestions to the Ministry of Economy and Communication administering the harbours. After fruitless attempts to obtain a positive response to solving the burning issue of city planning, Tallinn Municipality ordered by itself in 1997 a research for the development of the harbours, railroad juncture, and road transportation connections.

The company Eesti Tööstusprojekt (The Estonian Industrial Project Ltd.) conducted a research in 1998, which provided an overview of the condition and problems of the harbours in Tallinn and contained a number of suggestions for respecializing the harbours and municipalizing some of them to make the activities of the harbours from the perspective of both its owner and the city more purposeful, safer to the environment and the population in general (Nõmme 1998).

Muuga Bay and Muuga Harbour play a special role in the development of the coasts in the Tallinn area. Muuga Harbour has developed into one of the major oil transit harbours of the Baltic Sea region. It could relieve the load of the other harbours within Tallinn Bay and develop also other transport and services. How- 
ever, the harbour is dangerous in a strong northerly wind and impossible to handle in case of gale. Therefore, the coastal protection and development of Muuga Harbour are considered in a separate section of the present discussion.

\section{TALLINN MUNICIPALITY ISSUES AND ACTIVITIES}

The main role of Tallinn Municipality is the regulation of cooperation and participation in planning and realizing the measures for the protection and development of the coasts located within the administrative boundaries of Tallinn. The major problem is the cooperation of the Municipality with the organs of the state, aimed at increasing the role of the Municipality as the owner of the coasts and harbours in the Tallinn area. In Tallinn the coastal protection and harbours are under the administration of the Municipal Engineering Services Department.

At present the following activities concerning the coasts of the Tallinn area are in progress:

1. The coastal facilities, moles, and breakwaters of Patareisadam (Linnahalli) Harbour and the area surrounding the City Hall - it has been planned to expand Patareisadam Harbour for the reception of large vessels, tidy up the area for the common weal, and reinforce the coast outside the boundaries of the harbour.

2. The right bank of the Pirita River estuary with coastal facilities, also moles, breakwater, and waterway of Pirita Harbour - these constructions are owned by Tallinn Municipality and it is planned to develop here a harbour for smaller craft.

3. The reinforcement of the south coast of Tallinn Bay by the road from Kadriorg to Pirita is partially damaged and needs inspection and repair. The remaining portion of the road needs either repair or renovation.

4. The care and protection of Aegna Island and the restoration of Aegna Harbour. Aegna used to be a popular place for resting and a region of summer cottages. In the meantime the use of the island decreased drastically and both its coasts and the harbour were damaged by the storms. In the recent years the harbour was restored and the causes of coastal damage and the possibilities for the protection of the coasts were investigated (Orviku 2000). The storm of January 2005 hit Aegna, its coasts and harbour severely. The present task is to make the island again fit for use and open it to the inhabitants of Tallinn as a proper resting place. In future the harbour has to be reconstructed and made stronger and safer.

5. According to the decisions of the authorities of the local city districts, the Pirita and Kopli sandy coasts are tidied up for the common weal.

Tallinn is interested in increasing its role as the owner of the harbours located on the coasts of the city area. This is necessary for increasing future income of Tallinn and for better regulation of the use, defence, and development of the coasts. The state-owned Paljassaar Peninsula and Katariina Quay are of primary 
interest. For several reasons it would be purposeful to transform Miinisadam Harbour into a civil harbour and convey it to the city ownership. Also Lennusadam Harbour should be developed in the interests of the city. In order to reduce the transport of dangerous cargoes through the city centre, it is necessary to end the transit of oil products via Vene-Balti Harbour. For the complex development of the Tallinn harbours, the development plan for the harbours, connection roads between different harbours, and the railway juncture is needed. The harbours will be gradually re-specialized as passenger, tourism, and yacht harbours with the required infrastructure and security systems.

The farthest Aegna Island, an extension of the Viimsi Peninsula, is at present located in the administrative area of Tallinn. Naissaar Island, however, located farther from Viimsi, is part of the territory of Viimsi Rural Municipality. From the perspective of the administration, economic management of the islands, their protection and development, the assignment of Aegna Island to the administration of Viimsi Rural Municipality and Naissaar to Tallinn might be considered.

Cooperation with the other owners of the coasts and coastal buildings located within the administrative boundaries of Tallinn and participation in planning and accomplishing the measures for the protection and development of the coasts are carried out according to the regulations of Tallinn Municipality. In the same way, cooperation with the other local authorities in planning the protection and development of the coasts in the Tallinn area is carried out.

\section{PROTECTION AND DEVELOPMENT OF THE MUUGA HARBOUR AREA}

Muuga Harbour, administered by the Port of Tallinn Corp., is the largest and deepest harbour of Estonia, able to receive all the vessels transiting the Danish Straits. The harbour is provided with modern equipment and has rail and road connection with its hinterland. The unused coastal areas enable the harbour to enhance and vary the cargo flows, handle more cargo, and expand transit trade through Estonia. The harbour has thus far been used for the transit transport of oil products, but it could also take over a large portion of the cargo volume of the other harbours in Tallinn, relieve their load, and thus help Tallinn solve the harbour-related environmental issues.

However, the realization of the possibilities of Muuga Harbour and the expansion of its activities are hindered by the absence of the indispensable breakwaters. The breakwaters were already originally planned for the harbour, but have remained unbuilt thus far. One of the possible locations of breakwaters in Muuga Harbour is depicted in Fig. 4.

Due to the absence of breakwaters, it is difficult to use the harbour in case of a strong northerly wind, and downright impossible in case of a storm. Even the largest tankers are forced to disrupt the cargo operations once storm warning has been given and leave the harbour. The experience has shown the danger of such 
movings. For smaller vessels the harbour is dangerous without breakwaters and it is internationally known as an uncomfortable and unsafe harbour. In addition to the above circumstances, the lack of breakwaters poses great threat to the environment, because in case of a probable distress, the oil pollution can freely spread from the harbour to the Gulf of Finland. The waves of the northern storms can damage the harbour constructions and make the use of several harbour appliances impossible in winter due to ice. The construction of the breakwaters would increase and vary the cargo flows in the harbour and enhance the possibilities of the harbour to handle more cargo, and expand the volume of cargo transport through Estonia (Levald et al. 2003a).

The construction of Muuga Harbour breakwaters has been problematic due to the great depth of the sea, complex geological conditions, and probable environmental impacts. Also, the acquisition of the required amounts of building material may be difficult. The conducted preliminary assessment shows that these problems can be solved in a positive manner (Levald 2003a). These factors are of extreme significance for the Tallinn area and therefore we present here a brief summary of the research.

\section{Geology of the Muuga Harbour area}

The present review is based on numerous scientific papers and results of engineering-geological investigations performed in the Muuga Harbour area by different organizations in the years 1982-2000. Unpublished reports of these investigations housed in the Collection of Engineering Geology of the Estonian Land Board (EGF reports 18651, 20904, 24009, 24025, 26291, 27612, and 28250).

The Muuga Bay area has complicated geology, since it is located above an ancient buried valley falling into Muuga Bay north of Kroodi Brook. The valley is cut into the Cambrian blue clay and sandstone.

The blue clay of the Lontova Stage, and clay, silt, and sandstone of the Lükati and Tiskre formations are the oldest sedimentary rocks cropping out on land and sea floor. Total thickness of the sediments is $160 \mathrm{~m}$. The thickness of the blue clay is 40-70 m; on the territory of Muuga Harbour the drill-holes penetrate into the layer at $43 \mathrm{~m}$ b.s.l. The blue clay is underlain by the Vendian sand- and siltstones of the Kotlin Stage, which, in turn, overlie the crystalline basement.

The Quaternary cover consists of glacial, glaciolacustrine, and marine deposits. The blue clay is covered by purplish-grey loamy till, seldom by sandy loam till, which contains fragments of crystalline rocks and sandstone, and nests of blue clay. The thickness of till is variable, ranging from 2 to $8 \mathrm{~m}$, in places even more than $10 \mathrm{~m}$. The boundary with blue clay is transitional.

On most of the area a complex of soft soils (sandy loam, loam, and clay) overlies the till. The lower part of this complex is represented by varved clays and the upper part by marine varved sediments. The thickness of varves is variable, depending on the cyclicity of sedimentation. The total thickness of the clay complex is up to $9 \mathrm{~m}$. 
The marine deposits are represented mainly by mud and silt. Mud overlies the complex of varved clayey soils and contains sandy loam or loam; in places the mud is covered by silt rich in organic matter. The thickness of mud reaches $16 \mathrm{~m}$.

In the western and eastern parts of the bay the clayey complex is covered with yellowish-brown silt up to $9 \mathrm{~m}$ thick. The upper part of the mud bed may have been removed.

In the building area the thickness of fill may be considerable. The fill consists mostly of sand, with some rubble and limestone lumps. In places sand pumped from sea floor occurs, too.

\section{Soil properties and engineering-geological conditions}

The soils of the area of designed breakwaters have been studied by different organizations mainly under the leadership of P. Kildjer, mostly by penetration tests (Kildjer 1997). Several drill-holes have been made under the jetties and on the harbour water basin. The fill sand of the existing jetties is predominantly loose and has consolidated during several years due to its own weight and as a result of construction works when the jetties were reinforced.

The geotechnical properties of mud are poor, both varieties (with loam and sandy loam) are liquid in consistency and thixotropic. The water content of mud is $33-43 \%$, plasticity index $7-12$, void ratio $0.96-1.28$, and natural bulk density $17.7-18.5 \mathrm{kN} / \mathrm{m}^{3}$.

Glaciolacustrine and marine clayey soils are liquid to tough-plastic in consistency. In the upper part of the soil complex the content of laminae of silt, fine sand or tough-plastic silty sandy loam is greater, in deeper parts the proportion of clay fraction increases. The average organic matter content is $0.5 \%$.

The average water content of clayey soils is $32 \%$ and liquidity index 1.26 . The investigations made for the harbour buildings (reports EGF 26291 and 28250 in the Collection of Engineering Geology of the Estonian Land Board) show that the liquidity index increases in deeper ground, reaching 1.55.

Till is soft to hard plastic in consistency. The proportion of clay fraction increases with depth. The average water content of till is $22.5 \%$, plasticity index 16 , liquidity index 0.45 , and natural bulk density $20.3 \mathrm{kN} / \mathrm{m}^{3}$.

The natural bulk density of fine and medium sand overlying till is $18 \mathrm{kN} / \mathrm{m}^{3}$. The blue Lontova Stage clay is mainly semi-hard to hard, less often tough-plastic (on the slopes of the buried valley). In some investigations (e.g. report EGF 26291) the weathered and non-weathered parts have been distinguished on the basis of a decrease in the water content, the boundary being the water content of $18 \%$. The average water content of the weathered part is $21.5 \%$ and that of the non-weathered part $17.1 \%$. The plasticity index of blue clay is 21 and liquidity index 0.24 . The natural bulk density of the weathered part is $20.8 \mathrm{kN} / \mathrm{m}^{3}$ and of the non-weathered part $21.7 \mathrm{kN} / \mathrm{m}^{3}$.

The breakwater foundation conditions are satisfactory. A complex of weak clayey soils (clay, loam, and silt) occurs on the sea floor under the breakwater 
embankment, which should be covered by filling material in order to guarantee the stability of the breakwater. Due to the presence of weak clayey soils, a longterm continuous settlement of the breakwaters is likely to occur. Kildjer (1997) made respective calculations for the western jetty of Muuga Harbour. The thickness of the weak clayey soil complex was $17 \mathrm{~m}$ and the load from the jetty on the surface of this complex was $1 \mathrm{~kg} / \mathrm{cm}^{2}$. According to the calculations based on the consolidation properties of clayey soils (the latter were determined at the geotechnical laboratory of REI (Governmental Construction Institute)), the final settlement of the surface of the jetty due to the consolidation of clayey soils is $93 \mathrm{~cm} ; 50 \%$ of this will occur in 5 years, $85 \%$ in 15 years, and $96 \%$ in 30 years. It should be considered that the actual final settlement will be even greater because of the compaction of the embankment of a jetty.

It should be noted that the blue clay is very sensitive to leaching. The upper part the blue clay is weathered and therefore its geotechnical properties are altered. If the soils covering the blue clay are removed and covered with fill, the clay will be leached and its geotechnical properties will deteriorate even more, resulting in the worsening of breakwater foundation conditions.

The influence of waves on bottom deposits can affect the transport of bottom sediments at the entrance to Muuga Harbour, near the breakwaters. For the proper designing of the constructions, detailed geotechnical research is needed in the northern part of Muuga Bay.

\section{Possibilities of obtaining the material supplies for breakwaters and their costs}

Special research was made to evaluate profitability of breakwaters (costbenefit analysis) at Muuga Harbour, including the assessment of technological possibilities of construction and obtaining the material supplies for breakwaters (Levald 2003b). The research showed that in the geological conditions of Muuga Bay only two types of breakwaters are possible: (1) breakwaters of the rubble mound type or (2) a composite construction where the lower section of the breakwater was made up by a wall and the upper part was made of ferroconcrete caissons. In both cases the wide bottom of the wall lies directly on a specially prepared sea floor. Due to the geological peculiarities of the area mentioned above, a considerable sinking of the breakwaters in the course of time can be expected. In case of rubble mound breakwaters it is planned to compensate the sinking with increasing the mound periodically. The composite breakwater must be built with the height supply, reckoning with the further sinking.

A serious problem is how to obtain the filling material (sand, gravel, boulders) for the breakwater embankment. One option is to use the building refuse for filling, the other is to deliver these materials by ferries from Finland or extract them from the North Estonian Klint and transport to the ferries by slides. The fill cannot be transported on land by trucks because this is environmentally hazardous and of high cost. Obviously, at least some part of sand has to be taken from the sea floor. 
The possibilities of breakwater construction and its cost depend greatly on the opportunity to obtain the primary filling material of the rubble mound - limestone - and on its cost. The nearer and cheaper the required material can be acquired, the cheaper the breakwater construction and the smaller the risk of its realization. In an ideal case all the required material can be obtained from Estonia. In case of a rubble mound construction the limestone requirement amounts to a minimum of 3 million $\mathrm{m}^{3}$, in case of a rubble mound and the composite construction, to a minimum of 1 million $\mathrm{m}^{3}$. In order to get this amount, which is huge for Estonia, the following options could be considered:

- To obtain the required limestone from the as yet unbuilt second rank of Laagna Road and Tondiraba utilization areas. The opportunity needs to be co-ordinated with Tallinn Municipality. Advantages - the required filling material will be fetched from the near vicinity and at a relatively low cost. Disadvantages - the need to transport the filling material by road through a densely populated area.

- To obtain the material from the sales of the limestone material, coming from the dredging of the Ship Repair Yard that is going to be set up at Paldiski and from dismantling and transportation of the former Soviet Union defence and civil constructions. Advantages - opportunity to obtain relatively cheap material. Disadvantages - great distance, complications with material transportation and probable conflicts with the nature protection requirements while deriving the supplies from the klint escarpment.

- To obtain the material in agreement with the Estonian Maritime Administration from the dangerous shoals located near the Tallinn area. Advantages - the opportunity to get the material practically for free and improve the navigation conditions near Tallinn. Disadvantages - complications with finding the excavating mechanisms and the floating devices suitable for transportation and the suspended matter generated in the course of excavating and overturning that may endanger the sea ecosystem. The suitability and supply conditions of the material require further study.

- To obtain the material from the North Estonian Klint by building a temporary harbour. Advantages - opportunity to acquire high-quality material. Disadvantages - the absence of the floating devices, suitable for transportation and conflicts with the nature protection requirements.

The possibilities of obtaining the material supplies and the technical and organizational transportation issues are not yet solved in the present stage of the project. The transportation distances as well are still undetermined.

\section{Breakwaters and the environment}

Special research was made to assess the environmental impact of Muuga Harbour breakwaters (Levald 2003a). The results of the research show that the construction work and long-term existence of the breakwaters will have a distinctive, but mainly positive influence on the environment. Breakwaters will 
have a primarily positive impact on the social, economic, and artificial environment, and also on the environmental risks. There are no obstacles to the construction of the breakwaters from the environmental aspect.

\section{CONCLUSIONS}

The protection and development of the coasts in the Tallinn area is a complex issue, including on the one hand the geographical peculiarities and geological structure of the area, its water regime and weather conditions. Considering the cumulative effect of the above-mentioned factors, the area is suitable for living and port development. On the other hand, the economic and social development and the valid legal order have to be taken into account. The present paper highlights the geological peculiarities of the Tallinn area coasts and the dangers caused by the weather and water regime, necessitating the protection of the local coasts and influencing the development of the buildings located in port areas and in other coastal areas. It has been demonstrated that the most essential factors in coastal protection and development are the activities of the coastal area owners and the local authorities administering the coasts and their mutual cooperation. Such activities presume a purposeful legal order. The proprietary relations and legal order have undergone a drastic change in Estonia and are in need of further development. In the field of coastal protection, the expert planning and proper construction of coastal defence buildings are an essential issue. A significant issue is also the development of the harbours located within the boundaries of Tallinn mainly into passenger and tourist harbours, bearing in mind the Old Town of Tallinn and other valued cultural objects serving the interests of the city and its inhabitants, and the safety demands. A vital move in that direction is the development of Muuga Harbour, first of all the construction of its breakwaters, with a goal of creating the conditions for transferring there the cargo transport from the other Tallinn harbours. Due to local geological conditions it is a complicated and expensive task, but economically cost-effective, and in case of careful realization causes no environmental hazard, but reduces the danger of marine oil pollution. Tallinn Municipality has to increase its role in the regulation of the protection and development of coasts in the Tallinn area.

\section{ACKNOWLEDGEMENTS}

The paper has been composed on the basis of different research conducted at different time periods and financed by Tallinn Municipality, Port of Tallinn Corp., and other organizations. The authors are grateful to A. Raukas for a critical review of the article, to K. Orviku, J. Kask, P. Kildjer, and S. Roosma for the data regarding the condition and issues of the coasts in the Tallinn area, and to 
H. Udusaar for the description and photos of the damage to the Aegna Island coast. The valuable comments and recommendations of the referees Dr. Elvi Tavast and Prof. Guntis Eberhards are greatly appreciated.

\section{REFERENCES}

Järvik, A. (project leader) et. al. 2002. Rohuneeme sadama piirkonna merekanalite süvendustööd. KMH aruanne. Estonian Pilot, Tallinn (unpublished report).

Kildjer, P. 1997. Ehitusgeoloogilised tingimused naftaterminali ehitamiseks Muuga sadama läänemuulil. In Eesti Geotehnika konverents. Artiklite kogumik, pp. 26-34. Tallinn.

Künnapuu, S. \& Raukas, A. 1976. Pinnamood ja pinnakate. In Tallinna ajalugu kuni 1860. aastani (Pullat, R., comp.), pp. 20-36. Eesti Raamat, Tallinn.

Levald, H. (project leader), Raukas, A., Kask, J., Järvik, A., Lips, U. et al. 2003a. Preliminary environmental impact assessment of Muuga Harbour breakwaters. Estonian Maritime Academy, Tallinn (unpublished report).

Levald, H. (project leader), Raukas, A., Terk, E., Lend, E., Tiimann, A. et al. 2003b. Preliminary assessment of Muuga Harbour breakwaters profitability (cost-benefit analysis). Estonian Maritime Academy, Tallinn (unpublished report).

Levald, H. (project leader) \& Roosma, S. 2004. Rohuneeme paadisadama munitsipaalosa rajamise keskkonnamõju hindamine. Estonian Maritime Academy, Tallinn (unpublished report).

Nõlvak, J. 1997. Tallinn - its history and geology. In ProGeo '97 in Estonia. Excursion Guidebook (Viiul, A. et al., comp.), pp. 5-7. Estonian Ministry of Environment, Tallinn.

Nõmme, K. (project leader), Pihlak, I., Välja, H., Levald, H., Lend, E. et al. 1998. Tallinna piirkonna sadamate, raudteesõlme ja sadamate maismaaühenduste arengukava. ETP Group Ltd., Tallinn (unpublished report).

Orviku, K. 1987. Eesti rannik ja selle muutused. Eesti Loodus, 11, 712-719.

Orviku, K. 2000. Ekspertarvamus Aegna saare lääneranniku randade looduslikust seisundist. 08.09.2000 (unpublished manuscript).

Raukas, A. \& Hyvärinen, H. (eds). 1992. Geologiya Finskogo Zaliva. Institute of Geology, Estonian Academy of Sciences; Academy of Finland, Helsinki University; Tallinn (in Russian).

Soomere, T., Elken, J., Kask, J., Keevallik, S., Kõuts, T., Metsaveer, J. \& Peterson, P. 2003. Fast ferries as a new key forcing factor in Tallinn Bay. Proc. Estonian Acad. Sci. Eng., 9, 220-242.

Tammekann, A. 1934. Tallinna aseme pinnamoest. Eesti Loodus, 2, 31-37.

Tavast, E. \& Raukas, A. 1982. Rel'ef korennykh porod Éstonij. Valgus, Tallinn (in Russian).

Valt, V. et al. (eds). 1979. Tallinn. Lühientsüklopeedia. Valgus, Tallinn.

\section{Tallinna piirkonna rannikute kaitse ja arendamine}

\section{Heino Levald ja Ain Valdmann}

On käsitletud Tallinna piirkonna rannikute kaitset ja arendamist ennekõike sadamateks ja üldkasutatavateks rannaaladeks, mille rajamiseks on siin soodsad tingimused. Rannikut ja rannarajatisi ohustavad tugevad tormilained, eriti siis, kui tormiga kaasneb kõrge veeseis. Lainete mõjul taandub rannaastang maa suunas, lahtedes toimub liivade kuhjumine või ärakandumine. Tormidega on toimunud suured purustused Aegna saare ja Kakumäe poolsaare rannikul. Randade kaitseks 
on vaja arendada rannamaade omanike, kohalike omavalitsuste ja riigiorganite tegevust, korraldada nende omavahelist koostööd ja täiustada kehtivat õiguskorda. Tallinna piires kuuluvad rannad ja sadamad valdavalt riigile. Siin asuvate sadamate arengu kavandamisel on vaja arvestada reisijateveo ja mereturismi suurenemist Tallinna sadamate kaudu, keskkonnakaitset, ohutust ja linna majanduslikke huve, mida seni ei ole piisavalt tehtud. Tallinna piirkonna rannikute kaitse ja arendamise alal on tähtis osa Tallinna Linnavalitsusel. Linna piires asuvate randade ja sadamate haldamist on hakatud ümber korraldama.

Eriline osa Tallinna randade kaitse ja sadamate arendamise seisukohast on Muuga sadamal, mis võiks üle võtta suure osa Tallinna linna piires asuvate sadamate kaubavedudest. Sadama ohutuseks on vaja rajada lainemurdja. Raskete geoloogiliste tingimuste tõttu on see keerukas ja kallis. Teostatud uuringud näitavad, et lainemurdja rajamine suurendab oluliselt sadama ohutust ning on majanduslikult otstarbekas. 